\title{
声門形成術（Conley 法）の経験
}

\author{
本庄簏・田辺 正博・楠本 健夫 \\ 高島 凱夫*・福武 知重**
}

Experience of Conley's Glottic Reconstruction

\author{
Iwao Honjo, Masahiro Tanabe and Takeo Kusumoto \\ (Kochi Medical School) \\ Yoshio Takashima \\ (Kita-teishin Hospital, Osaka) \\ Tomoshige Fukutake \\ (Kochi City Hospital)
}

Three patients with early-stage laryngeal cancer (glottic, $\mathrm{T}_{1} \mathrm{~N}_{0} \mathrm{M}_{0}$ ) were treated by the surgery of Conley's glottic reconstruction. Abilities of swallowing and phonation after the surgery were found to be satisfactory. The surgical procedure was improved in the following two points: 1. The vocal cord was made by a skin ridge instead of a skin roll to facilitate voice production. 2. An opening was made in the thyroid cartilage to avoid excessive pressure on the base of the skin flap. The case indicated for this surgery has the indication of irradiation, too. This surgical procedure, however, seems to be more suited for the treatment of early cancer of the glottis in which preservation of acceptable voice is intended.

$$
\text { は じめに }
$$

声を保存する喉頭癌の手術, なかであ喉頭部分切除術に関しては従来から多くの手技の 報告1-8) がある，うち声帯切除後の声門を前頸部皮弁で形成する Conley 法"9) は，手技の容易さと成績の確 実さとで優れた方法と考えられる，以下本手術法を追試してみて気付いた点，あるいは改良した点 を述へ, 術後の曼下, 発声両機能についてもその成績を述べる.

\section{原法}

図 1 の如く, A : 甲状軟骨の高さで患側に茥 を持つ皮弁を作ったのち，喉頭截開術を行い一 側声带を含む腫瘍を切除する， B : 有茎皮弁上
に声带にあたる小皮膚棒を形成する，C：皮弁 を喉頭内に入れ先端を披裂部に縫合, 以下皮膚 棒を健側声帯レベルにあわせ創面に縫着する.

\footnotetext{
高知医科大学耳鼻咽喉科学教室

*大阪北聥信病院耳鼻咽喉科

**高知市民病院耳鼻咽喉科
} 


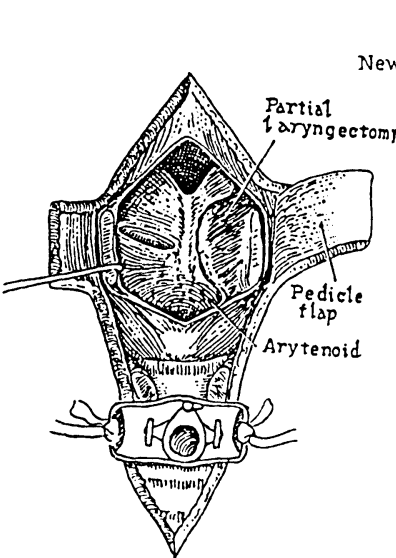

A

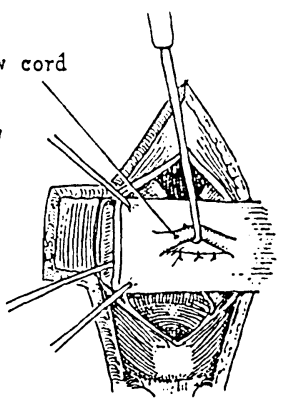

B

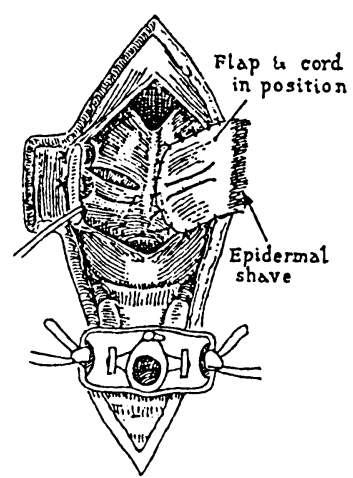

C

図 I:Conley の原法, A : 皮弁の形成と喉頭部分切除, B : 皮膚棒による新声帯, $\mathrm{C}:$ 皮弁の喉頭内縫着

更に対側軟部組織と接触する皮弁基部の脱上皮 を行う。

腫瘍切除が両声帯にわたる場合には，交叉す
る 2 つ有茎皮弁を作り，乙机らを喉頭内創面 に各々縫着し新声門を作る。

\section{症 例と手術 法}

症例 1 ：57才男子. 図 2 左の如く左声带に限 局する腫瘍を認めたが，患側声带の可動性は良 好であった．頸部リンパ節は触れない．すなわ ち glottic $\mathrm{T}_{1}$ NoMo. 生検で扁平上皮癌の診断 を得た。

症例 $2: 69$ 才男子. 図 2 中央の如く左声带に 腫瘍（扁平上皮癌）を認めた。この腫瘍は一部 声带下面に及んでいたが声門下領域にはいた らず，患側声带の運動性は良好であった。頸
部腫瘤は触知しない。従って本例む glottic $\mathrm{T}_{1}$ NoMo と診断された。

症例 $3: 87$ 才男子. 図 2 右の如く右声带に限 局する扁平上皮癌で, 声帯の可動性は良好であ った，頸部に腫瘤を触れない。すなわち glottic $\mathrm{T}_{1} \mathrm{NoMo}$ の症例であった。

手術法 : 以上の 3 症例に声門形成術を行った が，いずれも術中所見，手術操作に大差がない ので, 症例 1 亿つき詳述する.

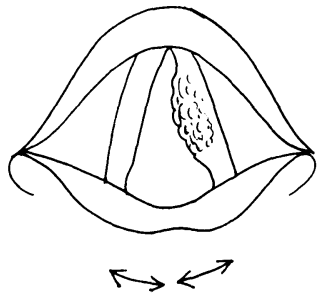

遈例 1

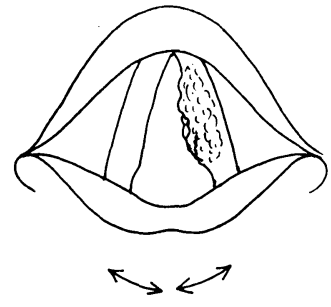

症例 2

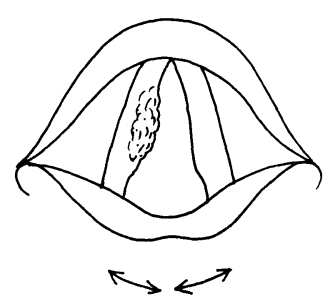

症例 3

図 2:3 症例の間接喉頭鏡所見 


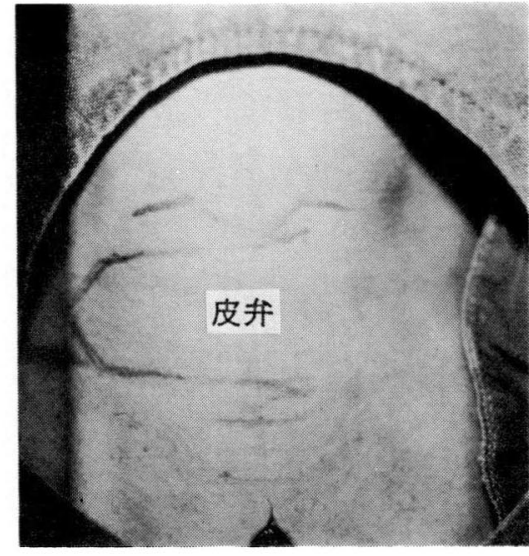

図 3 ：前頸部皮弁のデザィン

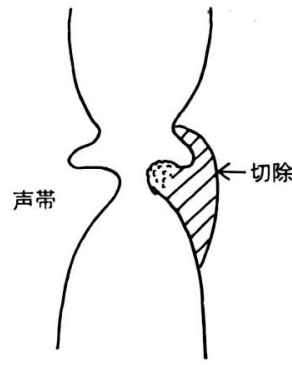

A

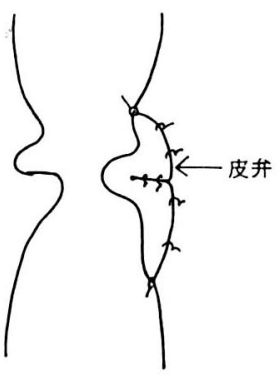

B
図 4：前額断喉頭像, $\mathrm{A}$ ：腫瘍の切除範囲, B：皮弁による声帯形成

図 3 の如く甲状軟骨の高さで，患側（左側） に茎を持つ皮弁 $(2 \mathrm{~cm} \times 4 \mathrm{~cm})$ を作製したの ち，喉頭を截開し，声带筋を含め左声带を腫瘍 と共に一塊として摘出した．切除範囲は図 4 , $\mathrm{A}$ の如く上方は仮声带下面，下方は声門下腔に 及び，前方は前交連，後方は披裂軟骨までとし た。迅速組織診断で切除断端に腫瘍を認め事 を確認したのち, 以下の声門形成に移った。

Conley の原法では有茎皮弁中に声带相当の 小皮膚棒を作製するが，我々は図 $4 \mathrm{~B}$ の如く声 帯に近似する皮膚隆起を作る方法をとった。 こ れを図 5 の様に喉頭内に入れ，皮弁先端をまず 披裂部に縫合し，以下順次ナイロン系による埋

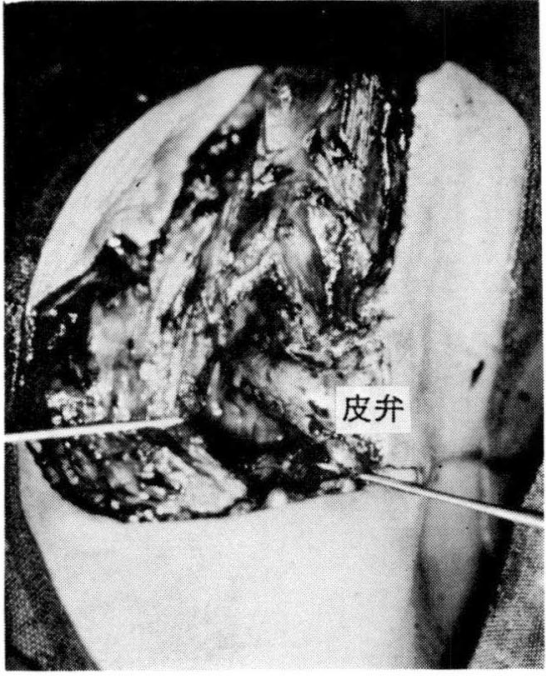

図 5：皮弁の喉頭内縫着

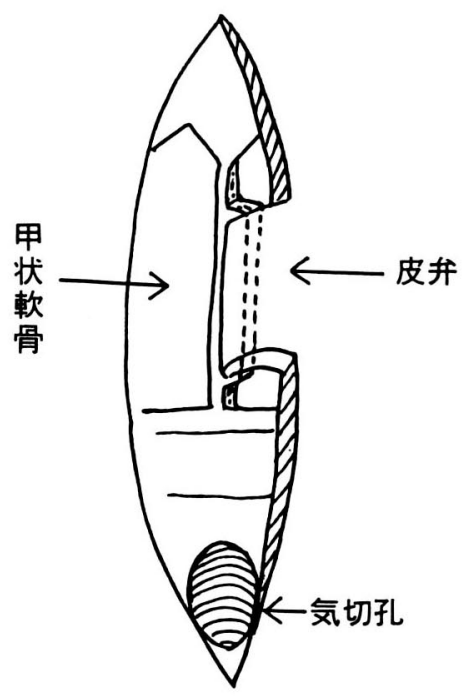

図 6：患側甲状軟骨の切除, 有空化

没縫合で皮弁を創面に縫着した.

喉頭を閉じる段階では原法通りに皮弁基部の 脱上皮を行い, 対側創面と縫合したが, この際 図 6 の如く患側甲状軟骨正中部をコの字形に切 除し，皮弁がこれに嵌入する様にした，皮弁採 取創は一次的に上下方向に縫縮した。 
結

a. 橫下 : 術後 $2 \sim 3$ 週目から経口摄食を開 始した，症例 1，2では誤嬹はなかったが, 症 例 3 で一過性に誤嚥をみた。 しかし数日で消失 し以後誤嚥をみていない.

b. 発声: 術後 $1 \sim 2$ 週間目の喉頭所見で は, 新声帯は浮腫状で運動性に乏しく, 高度の 嗄声であった. 術後 $3 \sim 4$ 週で誤嚥と呼吸困難 のない事を確認した上で，気切孔を閉じた，症
果

例 1 の術後 4 ケ月目の喉頭所見を図 7 に示す. 患側声帯の運動性は良好で, 発声時の声門間隙 あほとんどない．患側声帯は健側に比しやや巾 広く, 灰白色で表面平滑, やや湿潤である.

症例 1 の嗄声度の聴覚判定では術前は軽度気 息性㖽声, 術後 3 ケ月目の音声は術前之同程度 の気息性㖽声，ピッチは $135 \mathrm{~Hz}$, 発声持続時 間15秒， 発声時の呼気気流流率は $200 \mathrm{cc} / \mathrm{sec}$

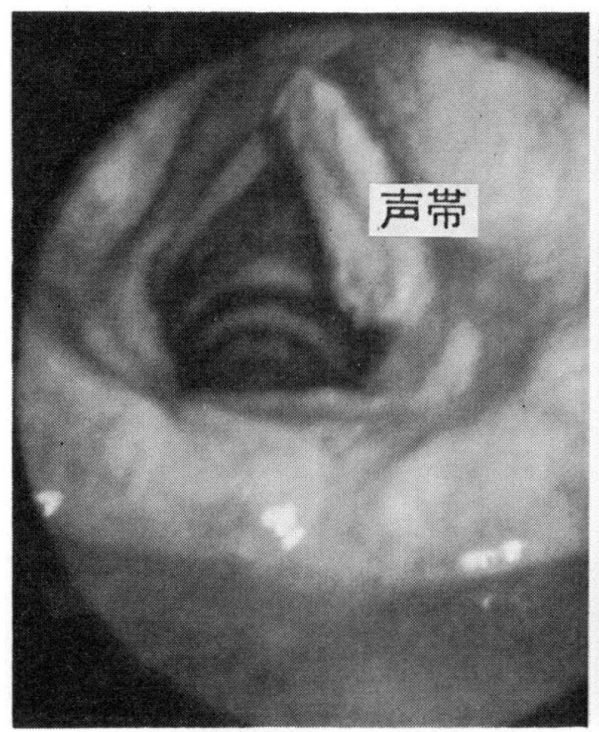

安静時

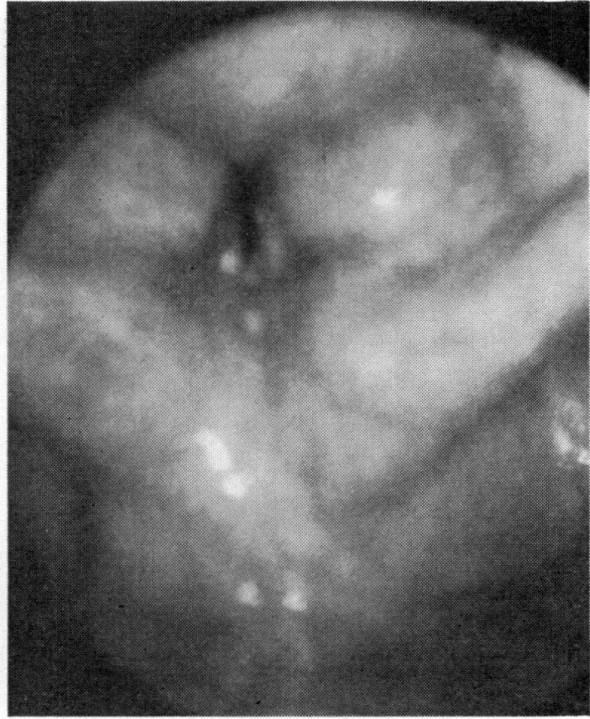

発声時

図 7 : 症例 1 の術後 4 ケ月目の喉頭所見 新声帯 (左側) は良く動く

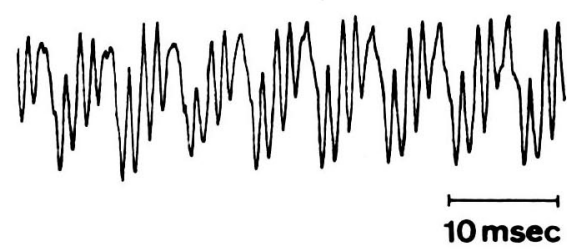

術前

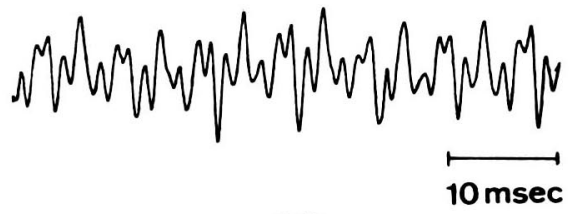

術後

図 8 : 症例 1 の術前, 術後の音声波形

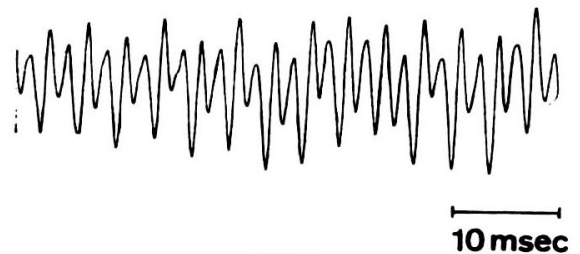

症例 2

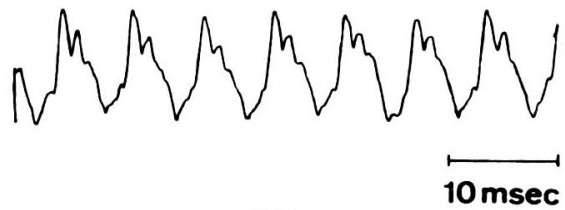

症例 3

図 9：症例 2,3 の術後の音声波形 
で正常範囲内にあった，症例 2 の術後の嗄声度 はやや高度の気息性嗄声, ピッチは $270 \mathrm{~Hz}$ 発 声持続時間 13 秒. 症例 3 の術後の嗄声度は軽度 気息性嗄声，ピッチは $155 \mathrm{~Hz}$ であった。症例 1

\section{考}

a . 手術適応について：本法の適応となる喉 頭癌は glottic $T_{1}$ NoMo であるが, glottic $\mathrm{T}_{2}$, すなわち両声带に腫瘍がわたるが声带の可 動性良好（披裂部に腫瘍浸潤がない）なタイプ も適応に含まれる。しかしての場合，交叉する 2 個の皮弁により新声門の再建を行うので皮弁 の巾は当然やや狭くなる。

glottic $\mathrm{T}_{1}$ の喉頭癌は同時に放射線治療の適 応でもあるが，前述の 3 症例の如く声带全長に わたる一定の質量をもつ腫瘍の場合，切除術は より確実な治療法と考えられた。本手術で声带 切除端から迅速組織診で腫湯浸潤を指摘され， 切除範囲を拡大した例があり, glottic $\mathrm{T}_{1}$ でも 深部浸潤例がある事を教えられた。

また術前診断から本法施行を意図した症例で 屯, 喉頭截開後の喉頭内腔所見で声带癌が声門 下腔に浸潤している場合には, 当然本手術法の 適応とはならず，喉頭垂直部分切除術，あるい は喉頭全摘出術に変更せねばならない。

b. 手術の注意点：(1)喉頭截開に先行して作 る有茎皮弁は，あとで修正不能であるから充分 に市広く長く，加厚いものにしておく. (2)原 法では皮膚棒形成を行うが，乙れは緊張性に之 しく声帯として非能率的と考えられたので, 我
の術前術後を図 8 に, 症例 2,3 の術後の音声 波形を図 9 に示す．症例 2 ではやや周期の乱れ が見られるが, 症例 $1 ， 3$ の術後の音声波形は 規則的である.

按

々は隆起形成法をとった．乙の場合隆起の平坦 化の恐れがあるので，確実な埋没縫合を 7,8 針行い，かつ隆起を過度に作る必要がある（3) 皮弁之声帯切除創との縫合は埋没縫合で密に行 い皮弁の生着をはかる．皮弁先端と披裂部との 縫合では，軟部組織が少ないので披裂軟骨の軟 骨膜，あるいは軟骨そのものと縫合せざるをえ ない（4)原法にはないが甲状軟骨の有空化は必 須で，乙れを行わないと両軟骨板の正中縫合に より, 有茎皮弁の基部は強く圧迫され壊死の危 険が生じる。

c. 㫶下，発声について：誤曣は原理的には 起ら筈であるが，1例で一過性にみられた。 これには恐らく87才という高令が関係している と思われた。

音声については術後も声带運動はよく保た れ, 発声時呼気流率を測定した 1 例では $200 \mathrm{cc}$ /sec と正常範囲内で，声門閉鎖は充分と考えら れた．術後の音声は，いずれの例であ嗄声であ ったが，皮膚によって形成された声帯が，やや 堅く，表面の移動性に乏しいととが主たる原因 と考えられた。発声持続時間も13〜15秒と長 く，嗄声を伴うとは言え，通常の会話に全く支 障はない音声が保存できた。

\section{ま と め}

Conley の声門形成術を glottic $\mathrm{T}_{1}$ NoMo の堠頭癌（扁平上皮癌） 3 症例に試み, 術後の噁下, 発声機能において好結果をえた。手術の改良点は原法の皮膚棒形成に代り皮膚隆起形成法とし，皮 弁基部が通る甲状軟骨の有空化を行った。本法適応例は同時に放射線治療の適応例でもあるが，本 手術法は腫瘍のより確実な治療法と考えられ，適応の範囲屯広く，試みるべき手術法と考え報告し た.

本論文の要旨は第46回耳鼻臨床会総会（金沢市）で発表した。 


\section{引用 文 献}

1) Figi F A. : Removal of carcinoma of larynx with immediate skin graft for repair. Ann Otolaryngol $59:$ 474 486, 1950.

2) Som M L. : Hemilaryngectomy-A modified technique for cordal carcinoma with extension posteriorly. Arch Otolaryngol $54: 524 \sim$ 533, 1951.

3) Pressman J J. : Cancer of the larynx : Laryngoplasty to avoid laryngectomy. Arch Otolaryngol $59:$ 395 412, 1954.

4) Maran A G D, Hart M H, Leonard J R. : Reconstructive surgery for improved glottic closure and voice following partial laryngectomy. Laryngoscope $78: 1916 \sim 1936,1968$.

5) Quinn H J. : A new technique for glottic reconstruction after partial laryngectomy. Laryngoscope $79:$ 1980 2011, 1969.
6) Ogura J H, Biller H F. : Glottic reconstruction following extended frontolateral hemilaryngectomy. Laryngoscope $79: 2181 \sim 2184$, 1969.

7 ) 広戸幾一郎：唉頭半側切除術一一声門再建の新し い術式. 耳鼻 18：293〜299，1972.

8 ) 平野実：喉頭垂直部分切除術後の声門再建法. 日 耳鼻 $79:$ 102 107, 1975.

$9)$ Conley J J. : Glottic reconstruction and wound rehabilitation: Procedures in partial laryngectomy. Arch Otolaryngol $74: 239 \sim$ 242, 1961.

$$
\begin{aligned}
& \text { 原稿到着：昭和56年10月 } 30 \text { 日 } \\
& \text { 別刷請求先：本庄 䉷 } \\
& \text { T781-51 高知県南国市岡豊町小蓮 } \\
& \text { 高知医科大学耳鼻咽喉科学教室 }
\end{aligned}
$$

